\title{
Significance of serum enzyme changes after cardiac catheterization and selective coronary arteriography
}

\author{
Masatsugu Hori, Michitoshi Inoue, Sugao Fukui, Toshiyuki Furukawa, Hiroshi Abe, \\ Takazo Minamino, and Nobuhisa Ohgitani \\ From the First Department of Medicine, Osaka University Medical School, Fukushima-ku, Osaka, and \\ the Sakurabashi Watanabe Hospital, Kita-ku, Osaka, fapan
}

The serum creatine kinase (CK), aspartate transaminase (AST), lactic dehydrogenase (LD) and $\alpha$-hydroxybutyric dehydrogenase (HBD) were determined before and 3, 6, 18, and 36 hours after cardiac catheterization and angiocardiography in 56 consecutive patients with ischaemic heart disease. Five of these patients whose serum enzyme levels were higher than normal before the procedure were excluded from the study. Forty-one of the remaining 51 patients had left ventriculography and also selective coronary arteriography. In these 41 patients (groups 1 and 2-see below), the mean serum CK levels increased after the procedure to exceed the upper limit of normal at every study interval. The mean serum $A S T, L D$, and HBD levels generally remained within the normal range at all study intervals, though serum AST increased abnormally in 9 of the 41 patients (22\%) and serum LD and HBD each increased above the normal limit in 2 of 41 patients (4.9\%).

In 24 patients (group 1) whose coronary arteriograms showed insignificant coronary narrowing ( $<75 \%$ ) in any of the three major coronary arteries, the increase in serum CK was significantly higher than in 17 patients (group 2) with greater than 75 per cent narrowings in at least one of the three major coronary arteries. However, the degree of serum CK elevation observed during the postangiographic period was much lower than that in another group of 30 consecutive patients with acute myocardial infarction. In 10 patients (group 3) who had the same procedure as groups 1 and 2 except without the selective coronary arteriography, the serum enzyme levels showed no noticeable increase after the procedure.

The difference in postangiographic serum CK elevation between patients with and without selective coronary arteriography and the difference between group 1 (without significant coronory narrowing) and group 2 (with significant narrowing) strongly suggest that the raised serum $C K$ levels represent some form of myocardial damage caused by the coronary arteriography, which, however, is different at least in degree from that of acute myocardial infarction.

Serum enzyme changes after cardiac catheterization and coronary arteriography play an important role in the clinical diagnosis of complicating myocardial infarction. However, controversy still exists as to the usual extent and the significance of these changes. Taquini et al. (1961) noted that serum transaminase (AST) levels were raised after transseptal left heart catheterization, and Adrouny et al. (1963) also noted the increase in serum AST in a significant number of subjects undergoing cardiac catheterization and angiography, whereas others found no significant

Received 13 June 1975 changes (Kochsiek and Engelhardt, 1965; Burkhardt et al., 1968). Serum creatine kinase (CK) has been reported in many studies to increase after cardiac catheterization and/or angiocardiography (Marpole et al., 1968; Michie et al., 1970), while no noticeable changes in serum lactic dehydrogenase (LD) and $\alpha$-hydroxybutyric dehydrogenase (HBD) were reported by Sitzmann and Gutheil (1966). These discrepancies may be caused by differences in the kind of cardiac disease and/or the procedures undertaken in these studies.

However, few studies have reported the serum enzyme changes after coronary arteriography (Michie et al., 1970; Chahine, Eber, and Kattus, 
1974), and there are no reports of investigations of the relation between the severity of coronary narrowing and the extent of serum enzyme changes after coronary arteriography. In this study in patients with ischaemic heart disease, serum CK, AST, LD, and HBD levels were determined before and after cardiac catheterization (left ventriculography with or without selective coronary arteriography) to investigate the correlation between coronary narrowing and the extent of serum enzyme increase.

\section{Subjects and methods}

The serum levels of CK, AST, LD, and HBD were measured before and $3,6,18$, and 36 hours after cardiac catheterization and angiocardiography in 56 consecutive patients with ischaemic heart disease. Five patients with abnormal serum enzyme levels before the procedure were excluded from the study. Of the remaining 51 patients, 41 patients (groups 1 and 2-see below) had cardiac catheterization, left ventriculography, and selective coronary arteriography without a major complication, while in 10 patients (group 3 as a control group) selective coronary arteriography was avoided because of complications such as arrhythmia and/or heart failure. One patient in group 3 complained of chest pain during the procedure. In the 41 patients of groups 1 and 2, no subjects had any clinical evidence of liver disease, skeletal muscle disease, pericarditis in the acute stage, or congestive heart failure during the study.

The 41 patients undergoing selective coronary arteriography were divided into two groups. Group 1 consisted of 24 patients (aged 43 to 66 years, average $50 \cdot 3$ years) whose coronary arteriograms showed less than 75 per cent narrowings in any of the three major coronary arteries. All of them showed minor obstructive lesions in one or two major caronary arteries except one patient with a variant form of angina who had no narrowing in any of the three vessels. This group consisted of 11 patients with a previous myocardial infarct ( 6 weeks to 2 years previously) and 13 patients with angina pectoris (8 patients with effort angina, 3 patients with variant form of angina, 1 patient with rest angina, and 1 patient with effort angina combined with variant form of angina). Group 2 consisted of 17 patients (aged 54 to 70 years, average 58.1 years) whose coronary arteriograms showed significant narrowings $(>75 \%)$ at least in one of the three major coronary arteries. This group consisted of 14 patients with previous myocardial infarction and 3 patients with angina pectoris ( 2 patients with effort angina and 1 with a combination of effort, rest, and variant form of angina).

Group 3 consisted of 10 patients undergoing cardiac catheterization and left ventriculography but without selective coronary arteriography. The age of the patients in this group ranged from 38 to 60 (average $52 \cdot 2$ years). There were 4 patients with previous myocardial infarction, 4 patients with angina pectoris (2 patients with effort and rest angina, 2 with variant form of angina), and 2 with atypical chest pain.

The previous myocardial infarctions were diagnosed by clinical history and electrocardiographic examination before the catheterization and, in some cases, the diagnosis had been confirmed by serum enzyme increases in the acute stage. Effort angina was diagnosed with the ergometer exercise test and the diagnosis of rest and variant form of angina was made on the basis of typical chest pain and the electrocardiographic changes during an attack.

Left ventriculography, using $40-50 \mathrm{ml}$ contrast medium (Urografin 76: sodium diatrizoate) was performed in all patients after premedication using oral diazepam $(10 \mathrm{mg})$ and intramuscular atropine sulphate $(0.5 \mathrm{mg})$ and hydroxyzine $(50 \mathrm{mg})$. Selective coronary arteriography was performed using a total of 30 to 40 $\mathrm{ml}$ of the same contrast medium given by four manual injections. The transfemoral percutaneous approach was used for right and left heart catheterization and angiography. Nitroglycerin $(03 \mathrm{mg}$ ) was administered sublingually just before the selective coronary arteriography was done. The cardiac output was determined by the dye-dilution technique in all patients (groups 1, 2, and 3).

The enzyme assays were performed either immediately after sampling or within 15 hours after separation of serum (stored at $4^{\circ} \mathrm{C}$ ). The normal values and determination method of serum enzyme levels in our laboratory are: for CK (less than $40 \mathrm{IU}$ ) method of Nuttall-Wedin (Nuttall and Wedin, 1966); for AST (0 to 40 units) modified method of Reitman-Frankel (Reitman and Frankel, 1957); for LD (30 to 140 units) method of Naclas (Naclas et al., 1960) and for HBD (40 to 170 units) modified method of Rosalki (Rosalki and Wilkinson, 1960).

As a comparative study, 30 consecutive patients with acute myocardial infarction were studied. In this group, serum levels of CK, AST, LD, and HBD were determined 6, 18, and 36 hours after the onset of chest pain.

Statistical evaluation of the data was done by applying Student's t-test.

\section{Results}

Table 1 shows the serum enzyme levels before and after cardiac catheterization and left ventriculography with or without selective coronary arteriography in 51 patients (groups 1,2 and 3). The serum enzyme changes in 41 patients (groups 1 and 2) who had selective coronary arteriography are illustrated in Fig. 1. In the 41 patients, the mean serum CK levels significantly increased $3,6,18$, and 36 hours after the procedure $(P<0.001)$ with the maximal mean value of $48 \cdot 1 \pm 4 \cdot 1$ IU which was 3.5 times higher than the mean value before the procedure, occurring 6 hours after the conclusion of coronary arteriography. The mean serum AST levels increased from 25.0 \pm 0.9 units to $30.2 \pm 1.3$ units and $31.4 \pm 1.8$ units at 3 and 6 hours after the procedure, respectively. Though these serum AST increases were statistically significant $(P<0.01)$, they remained within the normal range. As to individual variations, serum 
TABLE 1 Serum enzyme levels (mean $\pm S E$ ) before and after cardiac catheterization, left ventriculography with or without selective coronary arteriography in groups 1, 2, and 3

Group $1(n=24)$

\begin{tabular}{|c|c|c|c|c|c|}
\hline \multirow{2}{*}{$\begin{array}{l}\text { Serum } \\
\text { enzyme }\end{array}$} & \multirow{2}{*}{$\begin{array}{l}\text { Before } \\
\text { catheterization }\end{array}$} & \multicolumn{4}{|c|}{ After coronary arteriography } \\
\hline & & $3 \mathrm{hrs}$ & $6 \mathrm{hrs}$ & $18 \mathrm{hrs}$ & 36 hrs \\
\hline $\begin{array}{l}\text { CK } \\
\text { AST } \\
\text { LD } \\
\text { HBD }\end{array}$ & $\begin{array}{l}14 \cdot 9 \pm 1 \cdot 9 \\
26 \cdot 1 \pm 1 \cdot 3 \\
88 \cdot 8 \pm 3 \cdot 0 \\
94 \cdot 0 \pm 4 \cdot 9\end{array}$ & $\begin{array}{c}58 \cdot 6 \pm 10 \cdot 0^{\star \star} \\
31 \cdot 5 \pm 1 \cdot 7 \\
97 \cdot 3 \pm 3 \cdot 9 \\
109 \cdot 4 \pm 5 \cdot 0\end{array}$ & $\begin{array}{c}64 \cdot 1 \pm 6 \cdot 5^{\star \star} \\
32 \cdot 3 \pm 1 \cdot 8^{\star} \\
97 \cdot 5 \pm 4 \cdot 5 \\
116 \cdot 5 \pm 4 \cdot 2^{\star}\end{array}$ & $\begin{array}{c}58 \cdot 3 \pm 6 \cdot 0 \star \star \\
28 \cdot 9 \pm 1 \cdot 8 \\
87 \cdot 4 \pm 3 \cdot 9 \\
100 \cdot 3 \pm 4 \cdot 4\end{array}$ & $\begin{array}{l}52 \cdot 8 \pm 5 \cdot 6^{\star \star} \\
30 \cdot 8 \pm 2 \cdot 4 \\
86 \cdot 8 \pm 3 \cdot 5 \\
88 \cdot 8 \pm 3 \cdot 8\end{array}$ \\
\hline
\end{tabular}

Group $2(n=17)$

\begin{tabular}{llcccc}
\hline \multirow{2}{*}{$\begin{array}{l}\text { Serum } \\
\text { enzyme }\end{array}$} & $\begin{array}{l}\text { Before } \\
\text { catheterization }\end{array}$ & $3 \mathrm{hrs}$ & $6 \mathrm{hrs}$ & $18 \mathrm{hrs}$ & $36 \mathrm{hrs}$ \\
\cline { 2 - 6 } & $11 \cdot 8 \pm 1 \cdot 6$ & $20 \cdot 4 \pm 2 \cdot 4^{\star}$ & $25 \cdot 5 \pm 3 \cdot 8^{\star}$ & $21 \cdot 9 \pm 4 \cdot 2^{\star}$ & $19 \cdot 7 \pm 2 \cdot 9^{\star}$ \\
CK & $23 \cdot 5 \pm 1 \cdot 1$ & $28 \cdot 4 \pm 3 \cdot 0$ & $30 \cdot 1 \pm 3 \cdot 6$ & $22 \cdot 5 \pm 3 \cdot 0$ & $26 \cdot 8 \pm 3 \cdot 1$ \\
AST & $89 \cdot 1 \pm 4 \cdot 1$ & $95 \cdot 6 \pm 5 \cdot 0$ & $96 \cdot 5 \pm 4 \cdot 0$ & $95 \cdot 5 \pm 8 \cdot 1$ & $97 \cdot 0 \pm 7 \cdot 5$ \\
LD & $117 \cdot 1 \pm 7 \cdot 3$ & $119 \cdot 1 \pm 8 \cdot 0$ & $125 \cdot 0 \pm 9 \cdot 6$ & $135 \cdot 5 \pm 19 \cdot 7$ & $119 \cdot 6 \pm 15 \cdot 0$ \\
HBD & & & &
\end{tabular}

Group $3(\mathbf{n}=10)$

\begin{tabular}{|c|c|c|c|c|c|}
\hline \multirow{2}{*}{$\begin{array}{l}\text { Serum } \\
\text { enzyme }\end{array}$} & \multirow{2}{*}{$\begin{array}{l}\text { Before } \\
\text { catheterization }\end{array}$} & \multicolumn{4}{|c|}{ After left ventriculography } \\
\hline & & $3 \mathrm{hrs}$ & $6 \mathrm{hrs}$ & $18 \mathrm{hrs}$ & 36 hrs \\
\hline $\begin{array}{l}\text { CK } \\
\text { AST } \\
\text { LD } \\
\text { HBD }\end{array}$ & $\begin{array}{r}11 \cdot 3 \pm 2 \cdot 2 \\
22 \cdot 2 \pm 2 \cdot 1 \\
95 \cdot 4 \pm 4 \cdot 6 \\
101 \cdot 0 \pm 6 \cdot 8\end{array}$ & $\begin{array}{r}18 \cdot 1 \pm 3 \cdot 5 \\
23 \cdot 9 \pm 1 \cdot 9 \\
99 \cdot 6 \pm 4 \cdot 2 \\
114 \cdot 0 \pm 8 \cdot 5\end{array}$ & $\begin{array}{c}19 \cdot 2 \pm 4 \cdot 2 \\
28 \cdot 8 \pm 1 \cdot 7 \\
104 \cdot 0 \pm 5 \cdot 6 \\
115 \cdot 5 \pm 10 \cdot 2\end{array}$ & $\begin{array}{r}18 \cdot 4 \pm 3 \cdot 7 \\
23 \cdot 4 \pm 2 \cdot 4 \\
100 \cdot 8 \pm 5 \cdot 4 \\
106 \cdot 0 \pm 9 \cdot 4\end{array}$ & $\begin{array}{r}22 \cdot 2 \pm 3 \cdot 4^{\star} \\
22 \cdot 8 \pm 1 \cdot 7 \\
93 \cdot 2 \pm 5 \cdot 2 \\
103 \cdot 5 \pm 7 \cdot 8\end{array}$ \\
\hline
\end{tabular}

$\star$ Significantly different from the preangiographic value $(P<0.01)$

$\star \star$ Significantly different from the preangiographic value $(P<0.001)$

AST levels slightly exceeded the normal limit in 9 of 41 patients $(22 \%)$.

The mean serum LD and HBD levels did not show a significant increase at any study interval during the postangiographic period, with the exception of the serum HBD at 6 hours after the procedure, which was still within the normal range. Incidence of an abnormal increase in individuals in serum $L D$ and HBD after the procedure was 4.9 per cent ( 2 of 41 patients) each. There was only one patient who showed an abnormal increase in both serum LD and HBD.

In 10 -patients in group 3 who had the same procedure but without selective coronary arteriography, no serum enzyme levels showed abnormal increase, though the mean serum CK and AST levels increased slightly after the procedure (see Table 1).

In group 1 (the 24 patients with insignificant coronary narrowings) the serum $\mathrm{CK}$ levels in- creased significantly at every study interval after angiography $(P<0.001)$, with every mean value being much higher than the normal upper limit (see Fig. 2).

In group 2 (the 17 patients with significant coronary narrowing) in contrast to group 1, the serum CK levels were increased much less and in fact were much closer to the CK levels in the control group 3. The maximal mean value was observed 6 hours after the procedure in both groups: $64 \cdot 1 \pm 6.5 \mathrm{IU}$ in group 1 and $25.5 \pm 3.8 \mathrm{IU}$ in group 2. In group 3 (the 10 patients without selective coronary arteriography) the mean serum CK levels increased significantly only at 36 hours $(22.2 \pm 3.4$ IU, $P<0.01)$ but was still within the normal limit. There was no significant difference in serum $\mathrm{CK}$ levels between groups 2 and 3 at any study interval (see Fig. 2). In contrast to this, a significant difference $(P<0.001)$ in the postangiographic serum $\mathrm{CK}$ levels was noted at every 

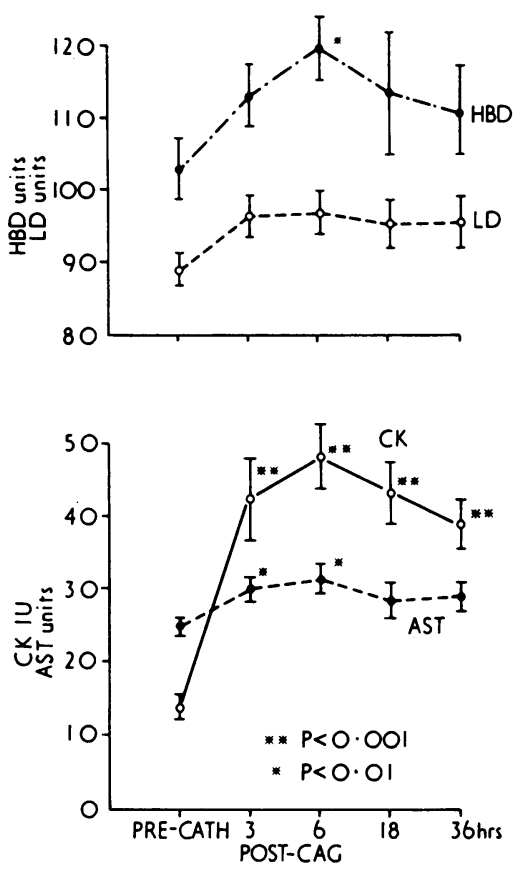

FIG. 1 Changes in serum enzyme levels (mean $\pm S E$ ) in 41 patients with ischaemic heart disease before cardiac catheterization (Pre-cath), and after (Postcag) left ventriculography and selective coronary arteriography.

* Significantly different from the preangiographic value $(P<0.01)$

**Significantly different from the preangiographic value $(P<0.001)$

study interval between groups 1 and 2, while the preangiographic values showed no significant difference between these two groups. A more remarkable difference was obtained when the patients with previous myocardial infarction from both groups were compared (11 patients in group 1 and 14 patients in group 2, see Fig. 3). The maximal mean value of serum CK obtained 6 hours after the procedure was $86.8 \pm 8.9 \mathrm{IU}$ in these patients in group 1 , but only $27.5 \pm 4.4 \mathrm{IU}$ in group 2 . The time from the onset of infarction to the angiographic examination showed no significant difference between the patients of these groups with previous myocardial infarction. There was also a difference in CK levels at 6 hours after the procedure between groups 1 and 2 in the patients with angina pectoris (13 patients in group 1, 3 in group 2), and the Student's t-test $(P<0.02)$ suggests that it is significant. The mean serum
AST levels increased slightly in group $1(P<0.01)$, but the maximal mean values in groups 1 and 2 , which were both within the normal range, showed no significant difference between these two groups (Fig. 4). The mean serum LD levels showed insignificant fluctuations within normal limits after the procedure. No significant difference was noted between the preangiographic and postangiographic mean HBD levels except for the mean value after 6 hours in group $1(P<0.01)$.

As a comparative study, the serum CK, AST, LD, and HBD were determined 6,18 , and 36 hours after the onset of chest pain in 30 consecutive patients with acute myocardial infarction. Table 2 shows the mean values of the various serum enzymes after the onset of infarction. All serum enzymes increased distinctly in acute myocardial infarction in comparison with those in the patients undergoing cardiac catheterization and angiography, though there was some individual overlap between the post-coronary arteriographic group (groups 1 and 2) and this control group. No individual overlap was observed between these groups in the serum LD and HBD levels at 18 and 36 hours.

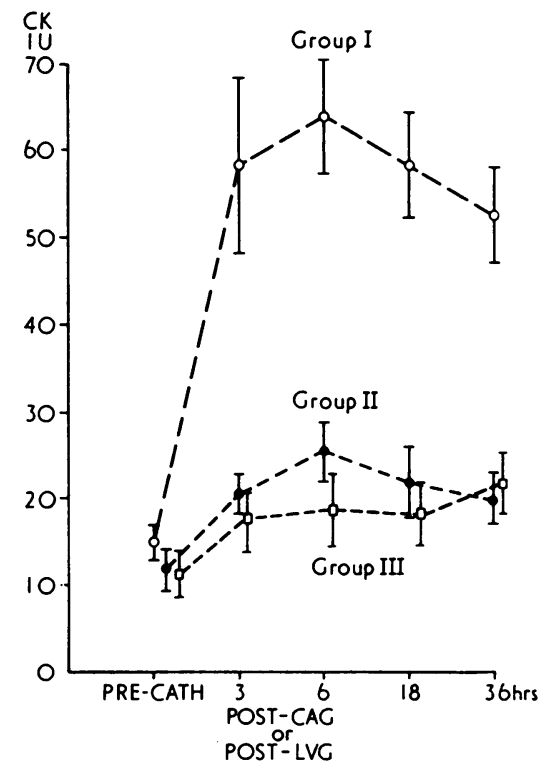

FIG. 2 Postangiographic serum CK levels (mean \pm $S E)$ in groups 1,2, and 3. Between groups 1 and 2, significant difference $(P<0.001)$ in the serum $C K$ levels was noted at every study interval after the procedure, while no significant difference was observed between groups 2 and 3. 


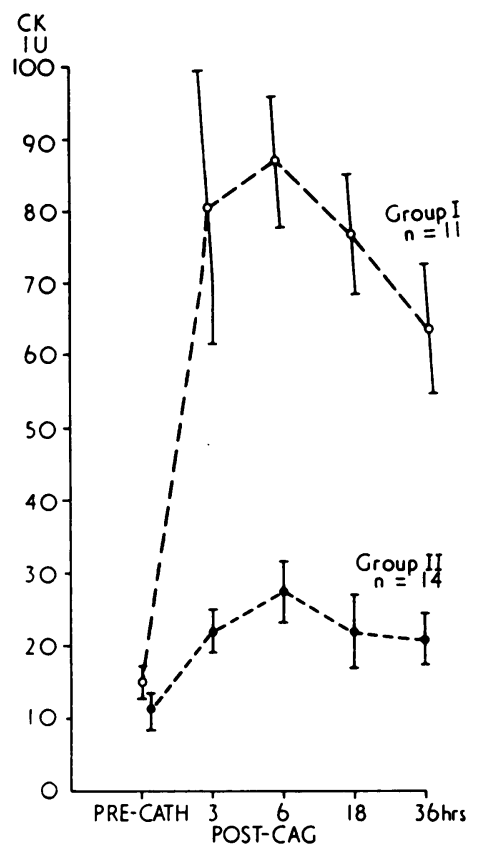

FIG. 3 Postangiographic serum $C K$ levels (mean \pm $S E)$ in patients of groups 1 and 2 with previous myocardial infarction. A distinct difference $(P<0.001)$ was observed between these two groups at every study interval.

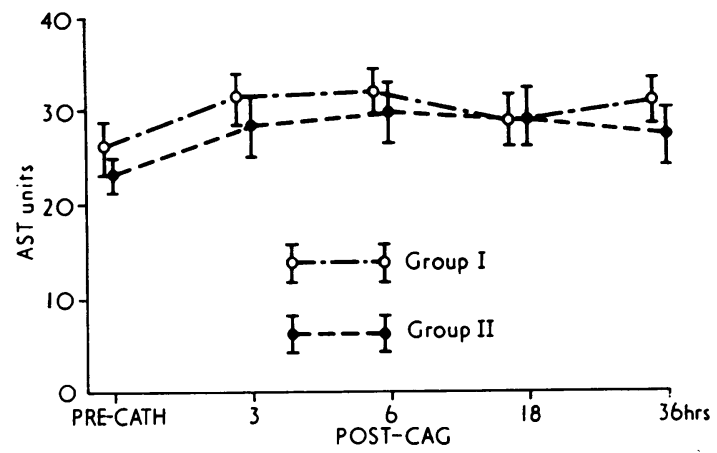

FIG. 4 Serum AST levels (mean $\pm S E$ ) of 41 patients with ischaemic heart disease in groups 1 and 2. No significant difference was observed between these two groups at any study intervals.

\section{Discussion}

Serum enzyme changes were studied in 41 patients with ischaemic heart disease before and after cardiac catheterization, left ventriculography and selective coronary arteriography, and in 10 patients after cardiac catheterization and left ventricul-
TABLE 2 Serum enzyme levels (mean $\pm S E$ ) in 30 consecutive patients with acute myocardial infarction

\begin{tabular}{lccl}
\hline \multirow{4}{*}{$\begin{array}{l}\text { Serum } \\
\text { enzyme }\end{array}$} & \multicolumn{4}{l}{ Hours after onset of infarction } \\
\cline { 2 - 4 } & $6 \mathrm{hrs}$ & $18 \mathrm{hrs}$ & $36 \mathrm{hrs}$ \\
\hline CK & $70 \cdot 5 \pm 11 \cdot 3$ & $244 \cdot 3 \pm 26 \cdot 8$ & $238 \cdot 2 \pm 33 \cdot 9$ \\
AST & $49 \cdot 5 \pm 4 \cdot 7$ & $154 \cdot 7 \pm 13 \cdot 9$ & $175 \cdot 6 \pm 21 \cdot 1$ \\
LD & $129 \cdot 3 \pm 11 \cdot 2$ & $302 \cdot 1 \pm 41 \cdot 7$ & $461 \cdot 0 \pm 63 \cdot 6$ \\
HBD & $178 \cdot 8 \pm 13 \cdot 9$ & $484 \cdot 2 \pm 51 \cdot 0$ & $784 \cdot 3 \pm 84 \cdot 0$ \\
\hline
\end{tabular}

ography but no selective coronary arteriography. A pronounced increase in the postangiographic serum CK levels was observed in the patients with insignificant coronary narrowings (group 1), while the serum CK levels in the patients with greater than 75 per cent coronary narrowings (group 2) and those without selective coronary arteriography (group 3) showed only a slight increase within the normal range. In contrast to CK, the mean values of other serum enzymesAST, LD, and HBD, showed minimal fluctuations within normal limits in all these groups. The significant difference in postangiographic serum $\mathrm{CK}$ levels between group 1 and groups 2 and 3 suggests that the raised serum CK levels could be attributed to the myocardial response to the injection of contrast medium and may reflect underlying myocardial conditions.

The significance and extent of the changes in serum enzymes after coronary arteriography have been studied extensively (Michie et al., 1970; Chahine et al., 1974), whereas those after cardiac catheterization and/or angiography, which have been reported by many authors, are often conflicting. For instance, Adrouny et al. (1963) reported that the serum AST exceeded the normal limit in 55 per cent of the subjects undergoing cardiac catheterization and in 33 per cent of the subjects who received angiocardiography, while Burkhardt et al. (1968) described no significant rise in serum AST in 113 patients using a similar procedure and significant increases in serum LD and HBD in only a few cases. These discrepancies could be due to the difference in the conditions of the study. Premedication, procedures of angiography, and the intervals of time the subjects were studied after the procedure were different in these different reports.

We determined the serum enzyme levels before and $3,6,18$, and 36 hours after cardiac catheterization, left ventriculography, and selective coronary arteriography in 41 patients with ischaemic heart disease. In our study, no significant increase was seen in serum LD and HBD except 
for minimal increase in serum LD in 2 of 41 patients $(4.9 \%)$ and in serum HBD also in 2 patients. The mean serum AST levels remained within the normal range at all study intervals, though the individual values slightly exceeded the normal upper limit in 9 of 41 patients (22\%). Chahine et al. (1974) described abnormal rises in serum AST in only 2 per cent of patients 24 hours after the cardiac catheterization and coronary arteriography. Our data, which showed the maximal increase at 6 hours after the procedure, suggests that they may have failed to detect the early rise in serum AST.

In our study, all 41 subjects received the same premedication and the same angiographic procedure including the approach of catheterization, and the type and amount of contrast medium. However, a much greater rise in serum CK during the postangiographic period was observed in the patients without significant coronary narrowings rather than in those with. When 25 patients of groups 1 and 2 with previous myocardial infarction were compared, an even more remarkable difference was observed in the $\mathrm{CK}$ rises between the 11 patients with significant coronary narrowings and the 14 patients without. The same tendency (i.e. less narrowing, the higher the rise in CK) was seen among 16 patients with angina pectoris, though there were only three angina patients in group 2 . We observed no noticeable increase in serum CK levels in 10 patients with ischaemic heart disease who received the same procedure with the same premedication except that selective coronary arteriography was avoided because of complications such as arrhythmia and/or heart failure.

These findings suggest that most of the increase in serum CK is of cardiac origin, and that the extracardiac factors such as the local tissue trauma at the site of introduction of the catheter and intramuscular premedication (as previously suggested by Crowley (1968) and Chahine et al. (1974)) contribute only minimally, if at all. The magnitude of serum CK rise during the postangiographic period, however, was much lower than that in the patients with acute myocardial infarction, though some overlap was seen between these two groups in the range of individual variations. In contrast to $\mathrm{CK}$, coronary arteriography did not produce a significant rise in the serum $L D$ and HBD levels. This may indicate that the myocardial damage caused by coronary arteriography is from a different mechanism than that of acute myocardial infarction. Wexler (1970) noted that serum CK is a sensitive index of not only myocardial necrosis but also of sarcolemmal membrane permeability. Whether the increase in serum $\mathrm{CK}$ after coronary arteri- ography is caused by transient ischaemia or by alteration of membrane permeability could not be determined from this study.

It is surprising that the serum $\mathrm{CK}$ increased in the patients without significant coronary narrowings (group 1), but not in the patients with significant coronary obstructions (group 2). This paradoxical observation may suggest either poor perfusion of contrast medium and/or a decreased number of myocardial cells which contribute to CK release in the patients with severe coronary narrowings. Hyperaemic response after intracoronary injection of contrast medium may also contribute to the release of $\mathrm{CK}$ from the myocardium. This speculation assumes additional interest in view of the report by Gould and Lipscomb (1974) of distinct hyperaemic response to contrast medium in coronary arteries without severe narrowings. Further investigations are necessary to clarify the mechanism by which $\mathrm{CK}$ is released from ischaemic myocardium after crronary arteriography.

We thank Dr. Frank Broun and Dr. Michihiko Tada for help in preparing the manuscript.

This study was supported in part by a research grant from the Mitsukoshi Health and Welfare Foundation.

\section{References}

Adrouny, Z. A., Stephenson, M. J., Straube, K. R., Dotter, C. T., and Griswold, H. E. (1963). Effect of cardiac catheterization and angiocardiography on serum glutamic oxaloacetic transaminase. Circulation, 27, 565.

Burckhardt, D., Vera, C. A., LaDue, J. S., and Steinberg, I. (1968). Enzyme activity following angiography. American fournal of Roentgenology, 102, 446.

Chahine, R. A., Eber, L. M., and Kattus, A. A. (1974). Interpretation of the serum enzyme changes following cardiac catheterization and coronary angiography. American Heart fournal, 87, 179.

Crowley, L. V. (1968). Creatine phosphokinase activity in myocardial infarction, heart failure, and following various diagnostic and therapeutic procedures. Clinical Chemistry, 14, 1185.

Gould, K. L., and Lipscomb, K. (1974). Effects of coronary stenoses on coronary flow reserve and resistance. American fournal of Cardiology, 34, 48.

Kochsiek, K., and Engelhardt, P. (1965). U'ber Aktivitatsanderungen von Enzymen in Blutserum nach Herzkatheteruntersuchungen. Klinische Wochenschrift, 43, 849.

Marpole, D., Judkins, M., Kloster, F., Marquardt, V., and Griswold, H. (1968). Elevated serum enzymes following coronary angiography. Circulation, 38, Suppl. V1-134.

Michie, D. D., Conley, M. A.. and Carretta, R. F. (1970). Serum enzyme changes following cardiac catheterizations with and without selective coronary arteriography. American fournal of Medical Science, 260, 11.

Naclas, M. N., Margulies, S. I., Goldberg, J. D., and Seligman, A. M. (1960). The determination of lactic dehydrogenase with a tetrazolium salt. Analytical Biochemistry, 1, 317. 
Nuttall, F. Q., and Wedin, D. S. (1966). A simple rapid colorimetric method for determination of creatine kinase activity. Fournal of Laboratory and Clinical Medicine, 68, 324.

Reitman, S., and Frankel, S. (1957). A colorimetric method for the determination of serum glutamic oxalacetic and glutamic pyruvic transaminases. American fournal of Clinical Pathology, 28, 56.

Rosalki, S. B., and Wilkinson, J. H. (1960). Reduction of $\alpha$-ketobutyrate by human serum. Nature, 188, 1110.

Sitzmann, F. C., and Gutheil, H. (1966). Serumenzymaktivitäten vor und nach der Herzkatheteruntersuchung bei Kindern. Zeitschrift für Kreislaufforschung, 55, 1218.
Taquini, A. C., Plesch, S. A., Badano, B. N., and de Winckler, E. O. B. (1961). Das Verhalten des C-Reaktiven-Proteins und der Serum-Transaminase nach der Herzkatheterisierung. Zeitschrift für Kreislaufforschung, 50, 1178.

Wexler, B. C. (1970). Serum creatine phosphokinase activity following isoproterenol-induced myocardial infarction in male and female rats with and without arteriosclerosis. American Heart fournal, 79, 69.

Requests for reprints to Dr. Masatsugu Hori, First Department of Medicine, Osaka University Medical School, Fukushima 1-1, Fukushima-ku, Osaka, Japan. 